\title{
BEBAN KERJA BERPENGARUH TERHADAP BURNOUT DENGAN VARIABEL WORK FAMILY CONFLICT SEBAGAI PEMEDIASI
}

\author{
I Made Agus Putra Wijaya ${ }^{1}$ \\ I Made Artha Wibawa ${ }^{2}$
}

${ }^{1}$ Fakultas Ekonomi dan Bisnis Universitas Udayana (Unud), Bali, Indonesia email: agusputra1531@gmail.com

\begin{abstract}
ABSTRAK
Tujuan dari penelitian ini adalah untuk menguji pengaruh beban kerja terhadap burnout dengan work family conflict sebagai variabel mediasi pada karyawan perempuan di PT Bank BRI Denpasar Gajah Mada. Dalam penelitian ini penentuan sampel menggunakan rumus slovin dengan metode purposive sampling, sampel yang digunakan adalah karyawan perempuan sebanyak 61 responden, melalui teknik analisis jalur (path analisis). Berdasarkan hasil analisis dapat diketahui bahwa beban kerja berpengaruh positif dan signifikan terhadap burnout pada karyawan perempuan di PT Bank BRI Denpasar Gajah Mada. Beban kerja berpengaruh positif dan signifikan terhadap work family conflict pada karyawan perempuan di PT Bank BRI Denpasar Gajah Mada. Work family conflict berpengaruh positif dan signifikan terhadap burnout pada karyawan perempuan di PT Bank BRI Denpasar Gajah Mada. Work family conflict memediasi pengaruh positif beban kerja terhadap burnout pada karyawan perempuan di PT Bank BRI Denpasar Gajah Mada.
\end{abstract}

Kata kunci : beban kerja, burnout, work family conflict

\begin{abstract}
The purpose of this study was to examine the effect of workload on burnout with work family conflict as a mediating variable on female employees at PT Bank BRI Denpasar Gajah Mada. In this study the determination of samples using Slovin formula with purposive sampling method, the sample used was female employees as many as 61 respondents, through path analysis techniques (path analysis). Based on the results of the analysis it can be seen that the workload has a positive and significant effect on burnout on female employees at PT Bank BRI Denpasar Gajah Mada. Workload has a positive and significant effect on work family conflict on female employees at PT Bank BRI Denpasar Gajah Mada. Work family conflict has a positive and significant effect on burnout in female employees at PT Bank BRI Denpasar Gajah Mada. Work family conflict mediates the positive effect of workload on burnout on female employees at PT Bank BRI Denpasar Gajah Mada.
\end{abstract}

Keywords: workload, burnout, work family conflict 


\section{PENDAHULUAN}

PT. Bank Rakyat Indonesia (persero) Tbk merupakan salah satu bank komersial terkemuka yang selalu mengutamakan kepuasan nasabah, PT. Bank Rakyat Indonesia (persero) Tbk selalu melakukan eskpansi bisnis bersamaan dengan peningkatan pelayanan kepada nasabah dalam berbagai bidang layanan perbankan, baik berupa layanan operasional maupun e-banking. Sebagai wujud ekspansi bisnis dari PT. Bank Rakyat Indonesia (persero) Tbk, maka setiap tahunnya PT. Bank Rakyat Indonesia Cabang Denpasar Gajah Mada diberikan target yang lebih tinggi minimal melampaui pencapaian kinerja ditahun sebelumnya. Untuk mencapai target tersebut, maka diperlukan penerapan strategi sumber daya manusia (SDM) yang tepat.

Manusia merupakan aset utama dalam organisasi, sehingga sumber daya manusia (SDM) harus dikelola dan dimanfaatkan secara seimbang dan manusiawi. Robins \& Coulter (2012) mengatakan bahwa sudah merupakan hal yang umum SDM merupakan aset terbesar bagi organisasi. Sedangkan Hasibuan (2018) mendefinisikan SDM mengacu pada kemampuan pekerja yang mempromosikan pembangunan ekonomi dan sosial secara keseluruhan, termasuk kemampuan kerja intelektual dan kerja fisik. Luthans (2012) menyatakan SDM bukan berarti hanya merujuk kepada manusianya saja tetapi kemampuan si karyawan tersebut, memberi pendapat bahwa bakat, kompetensi, ide, energi dari karyawan, produktivitas, dan kinerja dari organisasi secara kolektif diidentifikasikan sebagai SDM dari sebuah perusahaan.

Siagian (2015) berpendapat bahwa penerapan strategi SDM yang tepat akan memunculkan kemampuan untuk mendorong proses kreasi praktik-praktik SDM yang lebih inovatif, progresif dan berkinerja tinggi. Untuk mendukung penerapan strategi SDM yang tepat dibutuhkan manajemen sumber daya manusia yang baik. Manajemen sumber daya manusia merupakan salah satu faktor yang sangat penting untuk keberhasilan bisnis. Tanpa itu, tidak ada visi yang jelas, dan kesempatan akan tersia-siakan (Sonny, 2012).

Sumber daya yang terpenting adalah sumber daya manusia (human resources). Sumber daya manusia merupakan sumber daya yang digunakan untuk mensinergikan sumber daya lainnya untuk mencapai tujuan organisasi (Luthans, 2012). Tanpa SDM, sumber daya lainnya menganggur dan kurang bermanfaat dalam mencapai tujuan organisasi (Maeran et al., 2013). Peran karyawan sangat besar dalam mencapai keberhasilan perusahaan, hal yang perlu dipertimbangkan adalah kinerja karyawan yaitu pelayanan.Keberhasilan suatu perusahaan sangat ditentukan oleh pelayanan yang diberikan.Setiap perusahaan tentu selalu berusaha untuk meningkatkan kinerjakaryawannya, dengan harapan tujuan perusahaan juga tercapai (Siagian, 2015). Karyawan bukan semata obyek dalam pencapaian tujuan, tetapi juga menjadi subyek atau pelaku.Mereka dapat menjadi perencana, pelaksana dan pengendali yang selalu berperan aktif dalam mewujudkan tujuan perusahaan, serta mempunyai pikiran, perasaan dan keinginan yang dapat mempengaruhi sikapnya terhadap pekerjaan. Organisasi menginginkan karyawan yang bersedia melakukan tugas yang tidak tercantum dalam deskripsi pekerjaan mereka tanpa adanya rasa tekanan (Sonny, 2012). 
Keberhasilan suatu organisasi atau perusahaan dipengaruhi oleh kinerja karyawan. Pernyataan ini dirumuskan oleh Robins \& Coulter (2012) bahwa kinerja yang dilakukan karyawan merupakan suatu investasi untuk meningkatkan kinerja perusahaan. Hal ini disebabkan karyawan dituntut untuk memberikan waktu, tenaga dan usahanya untuk memperoleh apa yang mereka inginkan, misalnya keuntungan ekonomi, fellowship dan juga status sosial. Pentingnya kinerja karyawan karena kinerja adalah suatu potensi yang harus dimiliki oleh setiap karyawan untuk melaksanakan setiap tugas dan tanggung jawab yang diberikan organisasi. Dengan kinerja yang baik, maka setiap pegawai dapat menyelesaikan segala beban organisasi dengan efektif dan efisien sehingga masalah yang terjadi pada organisasi dapat teratasi dengan baik. Kinerja yang menurun disebabkan oleh menurunya kemampuan individu untuk secara normal dengan intensitas yang cukup tinggi akan mengakibatkan individu mengalami kelelahan secara psikis dan fisik yang disebabkan oleh situasi kerja yang tidak mendukung atau tidak sesuai dengan kebutuhan dan harapan yang biasa disebut dengan burnout. Burnout dimulai dengan kelelahan emosional yang merupakan respons terhadap stres kerja jangka panjang (Talachi \& Gorji, 2013).

Pada kondisi ini karyawan akan mengalami gangguan kesehatan secara fisik maupun secara psikis sehingga dapat mempengaruhi kinerja dalam pekerjaan. Burnout akan timbul ketika karyawan merasa mendapatkan tekanan pekerjaan, seperti tugas-tugas pekerjaan yang membebani mereka, hubungan dengan rekan kerja atau atasan, dan juga karena faktor gaji yang tidak sesuai dengan apa yang mereka harapkan. Burnout, adalah respons yang berlebih dari respons emosional kronis dan interpersonal stres saat bekerja, dan didefinisi oleh adanya kelelahan emosional, depersonalisasi dan berkurangnya pencapaian pribadi (Cohen \& Abedallah, 2015). Karyawan yang mengalami kelelahan emosional atau menghargai rendah dirinya sendiri, atau biasa disebut dengan istilah kejenuhan kerja (burnout) menyebabkan jalannya operasional perusahaan tidak akan tercipta dengan baik. Istilah kejenuhan kerja pertama kali dikemukakan oleh Freudenberg, seorang ahli psikologi klinis pada tahun 1974.

Hasil penelitian yang dilakukan oleh Maeran et al. (2013) menggambarkan hubungan terbalik antara pekerjaan dan keluarga: banyak orang mengimbangi kegagalan dan perasaan buruk mereka yang muncul di bagian kehidupan mereka melalui keterlibatan yang lebih besar di pihak lain. Profesi seseorang di bidang jasa menempati urutan pertama yang paling banyak mengalami intensitas kejenuhan kerja. Di antara profesi di bidang pelayanan, seseorang memiliki tingkat stres yang lebih tinggi dibandingkan dengan orang yang bekerja dibidang lainnya. Luthans (2012) menyatakan penyebab terjadinya kejenuhan kerja terdiri atas tiga dimensi yaitu kelelahan emosional, depersonalisasi, dan penurunan pencapaian prestasi pribadi. Kejenuhan kerja menyebabkan seseorang tidak memiliki tujuan dan tidak mampu memenuhi kebutuhan dalam bekerja. Tingginya stres yang harus di hadapi karyawan rentan terhadap munculnya gejala-gejala kejenuhan kerja (Purba et al., 2007).

Pekerja yang mengalami kejenuhan kerja menjadi berkurang motivasi dan ketertarikannya pada pekerjaan. Mengacu pada proses-proses psikologis yang menentukan awal, mengarahkan dan mempertahankan tindakan sukarela yang 
berorientasi pada suatu tujuan (Selvarajan et al., 2016) . Mereka mengalami kelelahan emosional, apatis, depresi, mudah tersinggung, dan merasa bosan. Mereka menemukan kesalahan pada berbagai aspek, yakni lingkungan kerja mereka, hubungan dengan rekan kerja, dan bereaksi secara negatif terhadap saran yang ditunjukkan pada mereka. Adapun ciri-ciri seseorang yang mengalami kejenuhan kerja (burnout) seperti sakit fisik berupa sakit kepala, demam, sakit punggung, tegang pada otot leher dan bahu, sering flu, susah tidur, dan rasa letih yang kronis (Puspitasari \& Handayani, 2014). Kelelahan emosi berupa rasa bosan, mudah tersinggung, sinisme, suka marah, gelisah, putus asa, sedih, tertekan, tidak berdaya. Kejenuhan kerja yang dialami individu dapat meningkatnya frekuensi karyawan untuk tidak masuk kerja, berhenti dari pekerjaan atau job turnover tinggi, sehingga kemudian berpengaruh pada efektivitas dan efisiensi kerja dalam organisasi (Purba et al., 2007) .

Pada pekerjaan yang memfokuskan diri pada pelayanan kemanusiaan yang lebih sering mengalami perasaan lelah secara fisik dan psikis. Hal ini terjadi karena banyaknya jumlah orang yang harus dilayani, pekerjaan yang harus siap setiap waktu ketika dibutuhkan untuk membantu orang lain, dan jam kerja yang melebihi waktu kerja yang biasanya serta tidak adanya pekerjaan yang tidak bisa dihindarkan. Penelitian Melati et al. (2015) menyatakan beban kerja memiliki pengaruh positif dan signifikan kejenuhan kerja pada karyawan. Hal yang sama dibuktikan oleh Fajriani \& Septiari (2015) tinggi rendahnya beban kerja memiliki pengaruh terhadap kejenuhan kerjapada karyawan.

Begitupun dalam penelitian Khandan (2015) burnout menyebabkan organisasi mengalami banyak tingkatan termasuk: penurunan kinerja staf, peningkatan kecelakaan, ketidakhadiran kerja, ketidakpuasan kerja, seringnya pergantian dan pergantian pekerjaan, berkurangnya kualitas kinerja kerja yang dapat menyebabkan penurunan kepuasan nasabah. Beban kerja memberikan pengaruh positif dan signifikan terhadap burnout pada karyawan Administratif Staff Shah Alam, Malaysia. Fajriani \& Septiari (2015) menyatakan hal yang sama bahwa beban kerja memiliki pengaruh positif dan signifikan terhadap kejenuhan kerja karyawan di Wilayah PT Sinar Sosro Semarang. Puspitasari \& Handayani (2014) beban kerja sangat berpengaruh positif dan signifikan terhadap burnout Guru Sekolah Inklusif Surabaya. Talachi \& Gorji (2013) menyatakan beban kerja berpengaruh positif dan signifikan terhadap burnout di Industry, Mine And Trade Organization Employees. Puspitasari \& Handayani (2014) menyatakan perilaku burnout karyawan disebabkan dengan adanya beban kerja yang tinggi karyawan.

Masalah beban kerja memiliki hubungan yang luas dengan work family conflict pada karyawan. Laeeque (2014) menyatakan konflik kerja-keluarga (WFC) adalah jenis bentrokan antar-tanggung jawab di mana tuntutan tanggung jawab dari lingkungan pekerjaan dan keluarga tidak dapat saling hidup bersama - dengan cara sedemikian rupa sehingga keterlibatan dalam peran pekerjaan (atau keluarga) menjadi lebih sulit karena adanya kebajikan keterlibatan dalam peran keluarga (atau pekerjaan). Salam (2014) Konstruk dua arah dari konflik kerja-keluarga terlihat jelas dalam literatur kerja-keluarga. Hasil wawancara yang dilakukan berdasarkan uraian tugas khususnya pada bagian SDM mengalami kesibukan yang padat hingga larut malam dalam pelaksanaan seleksi terhadap calon karyawan baru sesuai 
kebutuhan perusahaan, mengatur jadwal yang padat dalam usaha mengembangkan, meningkatkan kemampuan serta keterampilan tenaga kerja sesuai peraturan dan kebijakan perusahaan. Bertanggung jawab atas kegiatan operasional perusahaan kepada pimpinan cabang yang harus dilaporkan setiap bulan demi keberlangsungan perusahaan sedangkan pekerjaan lainnya belum selesai sepenuhnya.

Ariana \& Riana (2016) menyatakan secara umum, work family conflict adalah salah satu dari bentuk intern-role conflict yaitu tekanan atau ketidakseimbangan peran antara peran dipekerjaan dengan peran didalam keluarga yang akan berpengaruh terhadap burnout. Karyawan yang mengalami work family conflict akan merasa tidak senang dan tidak menikmati pekerjaannya. Beban kerja yang dirasakan karyawan mengakibatkan terjadinya konflik pekerjaan keluarga yang dapat menghabiskan waktu dan energi seseorang sehingga menyebabkan munculnya perasaan terancam dalam diri seseorang serta perilaku negatif dalam pekerjaannya (Laeeque, 2014). Masalah mengenai konflik pekerjaan keluarga yang dilihat dalam perusahaan terjadinya keluhan dari karyawan dalam bekerja, banyaknya permintaan dan pengaduan dari nasabah yang menyebabkan waktu jam kerja sering melebihi ketentuan sehingga minimnya waktu istirahat bagi karyawan dalam bekerja untuk memaksimalkan pelayanan.

Dewi \& Wibawa (2016) menyatakan permasalahan yang sering muncul mengenai karyawan pada saat mereka ditempatkan dalam kondisi waktu yang tidak bisa mereka tentukan, dengan kata lain mereka terikat jam kerja yang membuat mereka tidak bisa menghabiskan waktunya untuk bersama keluarga, disinilah muncul work-family conflict yang juga berpengaruh terhadap stres kerja yang secara tidak langsung menyebabkan burnout pada karyawan, hal ini dikatakan karyawan merasa pekerjaan tidak berpengaruh terhadap intensitas mereka bersama keluarga.

Penelitian Li et al. (2013), menjelaskan work-family conflict, memiliki efek langsung yang merugikan pada hasil terkait pekerjaan, konflik pekerjaan keluarga memberikan pengaruh positif dan signifikan terhadap burnout pada karyawan Industry in Malaysia. Salam (2014) menyatakan hal yang sama bahwa konflik pekerjaan keluarga memiliki pengaruh positif dan signifikan terhadap kejenuhan kerja karyawan di employees of Najafabad Islamic Azad University. Ariana \& Riana (2016) konflik pekerjaan keluarga berpengaruh positif dan signifikan terhadap burnout Hotel Amed Cafe dan Bungalow. Selvarajan et al. (2016) menyatakan konflik pekerjaan keluarga berpengaruh positif dan signifikan terhadap burnout. menyatakan konflik pekerjaan keluarga secara positif dan signifikan dapat meningkatkan perilaku burnout karyawan Industry in Pakistan.

Robins \& Coulter (2012) menyatakan isu sumber daya manusia memainkan peran penting, dalam hal ini perilaku di tempat kerja, perasaan dan persepsi kerja, faktor kepribadian pada pekerjaan khususnya, memiliki pengaruh penting terhadap organisasi. Salah satu isu utama dalam mengelola sumber daya manusia tentang profesinya sebagai karyawan. Saat ini, karyawan dirasakan menghabiskan lebih banyak waktu di kantor sebagai tempat kerja mereka. PT Bank BRI Cabang Denpasar Gajah Mada yang harus memberikan layanan kepada nasabah memberikan situasi yang kompleks dalam keadaannya sehingga tidak sedikit karyawan yang merasakan kejenuhan dalam bekerja. 
PT. Bank BRI Kantor Cabang Denpasar Gajah Mada beralamat di Jalan Gajah Mada No. 5-7 Dauh Puri Kangin Denpasar dengan 351 karyawan termasuk pimpinan cabang. Serangkaian kebijakan PT. Bank BRI dalam pekerjaan memberikan dampak terhadap kejenuhan kerja karyawan. Kejenuhan kerja merupakan hal yang harus diperhatikan oleh perusahaanjika perusahaan menghendaki setiap karyawannya dapat bekerja dengan baik. Karyawan yang merasa jenuh dalam melakukan pekerjaannya, akan sulit untuk bekerja dengan baik dan cenderung tidak bertanggung jawab sekalipun karyawan tersebut memiliki kemampuan operasional yang baik.

Kejenuhan kerja juga bisa terjadi akibat kurangnya penghargaan positif atas kerja yang selama ini dikerjakan. Kejenuhan kerjadi suatu perusahaan bisa diukur dari banyaknya pengunduran diri karyawan. Dimana karyawan mengatakan mengalami tekanan yang sangat tinggi pada saat bekerja, karyawan mengatakan pernah mengalami stres dengan tingkat yang berbeda-beda diantaranya karyawan yang sering mengalami stres, mulai stres bahkan sangat stres dengan beban kerja yang banyak (Robins \& Coulter, 2012). Standar yang ditetapkan oleh perusahaan berkaitan dengan peraturan, tenggang waktu kerja, upah (financial), lingkungan bahkan selalu dituntut memiliki konsentrasi dan kondisi fisik yang selalu prima memberikan dampak positif dan negatif pada karyawan. Dampak positif berupa meningkatnya motivasi karyawan sehingga berpengaruh terhadap prestasi kerja karyawan untuk mencapai target sesuai dengan standar yang telah ditetapkan diperusahaan, dengan harapan dapat memperoleh penghargaan dari atasan (pemberlakuan penghargaan dan hukuman oleh perusahaan). Dampak negatif bisa terlihat dari menurunnya prestasi kerja karyawan karena mendapat stres yang tinggi sehingga berpotensi untuk melakukan pelanggaran-pelanggaran di tempat kerja, apabila stres pada individu berlangsung secara terus menurus dan tidak dapat terselesaikan maka aka memicu timbulnya kejenuhan kerja. Kondisi inilah yang terjadi di dalam PT. Bank BRI Kantor Cabang Denpasar Gajah Mada dimana karyawan memiliki jam kerja yang padat (bekerja 8-10 jam sehari diluar jam kerja yang telah ditentukan).

Melalui pemaparan masalah yang telah dijabarkan, didukung dengan karya ilmiah dan teori tujuan dari karya ilmiah ini yang hendak dicapai 1) Apakah beban kerja berpengaruh terhadap burnout pada karyawan di PT. Bank BRI Kantor Cabang Denpasar Gajah Mada, 2) Apakah beban kerja berpengaruh terhadap work family conflict pada karyawan di PT. Bank BRI Kantor Cabang Denpasar Gajah Mada, 3) Apakah work family conflict berpengaruh terhadap burnout pada karyawan di PT. Bank BRI Kantor Cabang Denpasar Gajah Mada, 4) Apakah work family conflict memediasi pengaruh beban kerja terhadap burnout pada karyawan di PT. Bank BRI Kantor Cabang Denpasar Gajah Mada.

Teori atribusi (attribution theory) teori atribusi memberikan penjelasan tentang proses bagaimana kita menentukan penyebab/ motif perilaku seseorang (Robins \& Coulter, 2012). Teori ini diarahkan untuk mengembangkan penjelasan dengan cara-cara kita menilai orang secara berlainan, tergantung makna apa yang akan kita hubungkan (atribusikan) ke suatu perilaku tertentu. Teori atribusi itu sendiri, mengacu pada bagaimana seseorang menjelaskan penyebab perilaku orang lain/diri sendiri, yang ditentukan apakah dari faktor internal/ eksternal, maka akan 
terlihat pengaruhnya terhadap perilaku individu. Penyebab perilaku dikenal sebagai dispositional attributions dan situational attributions atau penyebab internal dan eksternal (Robins \& Coulter, 2012). Dispositional attribution atau penyebab internal mengacu pada aspek perilaku individual, sesuatu yang ada dalam diri seseorang seperti sifat pribadi, persepsi diri, kemampuan dan motivasi. Situational attributions atau penyebab eksternal mengacu pada lingkungan tempat kerja yang mempengaruhi perilaku, seperti kondisi sosial, nilai sosial, fungsi manajemen, sikap kepemimpinan, dan pandangan masyarakat.

Berdasarkan penjelasan yang telah diuraikan di atas, maka penelitian ini akan lebih mengacu kepada teori attribution theory. Karena attribution theory menjelaskan level karakteristik yang menyebabkan seorang karyawan melakukan perilaku burnout, yaitu karakteristik kondisi sosial, nilai sosial, fungsi manajemen, sikap kepemimpinan, dan pandangan masyarakat. Dari level organisasi tersebut, pada dasarnya diperkuat dengan adanya ketersediaan alternatif pekerjaan lain sehingga mendorong karyawan untuk memutuskan keluar dari perusahaan.

Kejenuhan kerja (Burnout)

Laeeque (2014) mengatakan bahwa kejenuhan kerjaadalah suatu sindrom kelelahan emosional, fisik, dan mental, berhubungan dengan rendahnya perasaan harga diri, disebabkan penderitaan stres yang intens dan berkepanjangan. Kejenuhan kerja merupakan respon yang berkepanjangan terkait faktor penyebab stres yang terus-menerus terjadi tempat kerja di mana hasilnya merupakan perpaduan antara pekerja dan pekerjaannya.

Robbins (1994) menjelaskan bahwa kejenuhan kerja meliputi kelelahan fisik, kelelahan mental, dan emosi yang disebabkan stres yang berhubungan dengan pekerjaan, yang biasa terjadi pada individu yang bekerja dalam bidang pelayanan sosial.Kelelahan fisik yang terjadi dapat meliputi merasakan berkurangnya tenaga, merasa lemah, atau kelelahan yang kronis.Kelelahan mental dapat dimunculkan dengan tingginya sikap negatif pada seseorang, pekerjaan, dan hidupnya. Kelelahan emosi terkait adanya perasaan tidak berdaya, tidak berpengharapan, dan merasa terjebak atau terperangkap dalam pekerjaannya.

Menurut Nasir \& Morgan (2017) terdapat dua faktor penyebab yang menimbulkan terjadinya kejenuhan kerja, yaitu: faktor eksternal/lingkungan kerja, yaitu kondisi pekerjaan yang buruk, kurang adanya promosi jabatan, prosedur aturan yang kaku, dan tuntutan pekerjaan, gaya kepemimpinan, dan faktor internal, yaitu usia, jenis kelamin, harga diri, dan kepribadian.

Menurut Sonny (2012) terdapat tiga komponen yang sering digunakan untuk menjelaskan terjadinya kejenuhan kerja, yaitu kelelahan emosi; pada kondisi ini, rasa lelah muncul begitu saja tanpa sebelumnya didahului oleh pengeluaran energi yang berarti.

Kejenuhan kerja dapat diukur dengan indikator Robbins \& Judge (2013): Kelelahan emosional, takut untuk kembali bekerja, mudah marah dan tersinggung, merasa depresi dan terjebak dalam pekerjaan. Kurang puas dengan hasil pekerjaan, memberi evaluasi negatif pada diri sendiri, perasaan kegagalan dalam bekerja.

Perubahan demografi tenaga kerja terhadap peningkatan jumlah wanita bekerja dan pasangan yang keduanya bekerja, telah mendorong terjadinya konflik antara pekerjaan dan kehidupan keluarga. Greenhaus \& Beutell (1985) 
mendefinisikan konflik pekerjaan keluarga (work family conflict) sebagai bentuk konflik peran di mana tuntutan peran pekerjaan dan keluarga secara mutual tidak dapat disejajarkan dalam beberapa hal. Konflik peran ini akan terjadi ketika pemenuhan tuntutan peran dalam keluarga dipengaruhi oleh kemampuan orang tersebut dalam memenuhi tuntutan pekerjaannya.

Robbins (2008:76) mendefinisikan konflik sebagai masalah internal dan eksternal yang terjadi sebagai akibat dari perbedaan pendapat, nilai-nilai, keyakinan dari dua orangatau lebih. Siagian (2015) bahwa konflik dapat dikategorikan sebagai suatu kejadian atau proses. Sebagai kejadian, konflik terjadi dari suatu ketidaksetujuan antara dua atau orang atau organisasi, dimana orang tersebut menerima sesuatu yang akan mengancam kepentingannya. Luthans (2012) menyatakan sebagai suatu proses, konflik dimanifestasikan sebagai suatu rangkaian tindakan yang dilakukan oleh dua atau lebih kelompok berusaha menghalangi atau mencegah kepuasan dari seseorang.

Berdasarkan definisi beberapa ahli, dapat disimpulkan Konflik pekerjaan keluarga terjadi ketika tuntutan pekerjaan dalam ketidakharmonisan dengan tuntutan keluarga. Tuntutan keluarga ini ditentukan oleh besarnya keluarga, komposisi keluarga dan jumlah anggota keluarga yang memiliki ketergantungan terhadap anggota yang lain

Robbins (2008:142) menyatakan bahwa konflik pekerjaan keluarga merupakan bentuk konflik dimana tuntutan peran dari pekerjaan dan keluarga secara mutual tidak dapat disejajarkan dalam beberapa haldi bidang pekerjaan dan lingkungan yang dapat di ukur melalui indikator sebagai berikut:

Kurangnya ketersediaan waktu bersama keluarga, adalah keadaan yang dirasakan karyawan kurang memiliki waktu bersama keluarga disebabkan jam kerja yang berlebihan. Adanya gangguan keluarga sehingga mengganggu produktivitas pekerjaan, adalah keadaan yang dirasakan karyawan karena gangguan dari keluarga sebab minimnya kebersamaan dengan keluarga.Adanya keluhan keluarga yang mengganggu pekerjaan, adalah keadaan yang dirasakan karyawan karena keluhan dari keluarga sehingga mengganu pekerjaan. Adanya beban kerja yang melebihi kapasitas tanggung jawab, adalah keadaan yang dirasakan karyawan terhadap beban kerja melebihi kapasitas tanggung jawab. Adanya tekanan dari peran kerja, adalah keadaan yang dirasakan karyawan terhadap tekanan dari peran kerja yang berlebihan. Kurangnya waktu istirahat dalam bekerja, adalah keadaan yang dirasakan karyawan terhadap tekanan kurangnya waktu istirahat dalam bekerja.

Beban kerja adalah istilah yang mulai dikenal sekitar tahun 1970. Banyak ahli yang telah mengemukakan definisi beban kerja sehingga terdapat beberapa definisi yang berbeda mengenai beban kerja.Ia merupakan suatu konsep yang multidimensi, sehingga sulit diperoleh satu kesimpulan saja mengenai definisi yang tepat (Luthans, 2011:65). Beban kerja sebagai perbedaan antara kemampuan karyawan dengan tuntutan tugas yang diterima.Beban kerja itu dapat berupa beban kerja fisik dan beban kerja mental.

Robbins (2008:128) juga mengatakan bahwa beban kerja adalah keadaan dimana pekerjaan dihadapkan pada tugas yang harus diselesaikan pada waktu tertentu. Kategori lain dari beban kerja adalah kombinasi dari beban kerja kuantitatif dan kualitatif. Beban kerja secara kuantitatif yaitu timbul karena tugas- 
tugas terlalu banyak atau sedikit, sedangkan beban kerja kualitatif jika pekerja merasa tidak mampu melaksanakan tugas atau tugas tidak menggunakan keterampilan atau potensi dari pekerjaan.Beban kerja fisik atau mental yang harus melakukan terlalu banyak pekerjaan, merupakan kemungkinan sumber stres pekerja.

Definisi beban kerja dalam penelitian ini adalah beban kerja sebagai perbedaan antara kemampuan karyawan dengan tuntutan tugas yang diterima.Beban kerja dapat berupa beban kerja fisik dan beban kerja mental, yang merujuk pada dimensi yang dikemukakan oleh Hart dan Staveland.

Luthans (2007:65) membagi beban kerja fisik dan mental menjadi enam dimensi, ukuran beban kerja fisik meliputi physical demand, dan effort. Dan ukuran beban kerja mental meliputi mental demand, temporal demand, performance dan frustration level yaitu:Permintaan fisik (Physical demand), yaitu besarnya aktivitas fisik yang dibutuhkan dalam melakukan tugas (contoh: mendorong, menarik, memutar, mengontrol, menjalankan dan lainnya), upaya (Effort), yaitu usaha yang dikeluarkan secara fisik dan mental yang dibutuhkan untuk mencapai level performansi karyawan, permintaan mental (Mental demand), yaitu besarnya aktivitas mental dan perseptual yang dibutuhkan untuk melihat, mengingat, dan mencari. Pekerjaan tersebut mudah atau sulit, sederhana atau kompleks, dan longgar atau ketat, permintaan sementara (Temporal demand), yaitu jumlah tekanan yang berkaitan dengan waktu yang dirasakan selama pekerjaan berlangsung. Pekerjaan perlahan atau santai atau cepat, dan melelahkan tingkat frustasi (Frustation level), yaitu seberapa tidak aman, putus asa, tersinggung, terganggu, dibandingkan dengan perasaan aman, puas, nyaman, dan kepuasan diri yang dirasakan. Kinerja (Performance), yaitu seberapa besar keberhasilan seseorang di dalam pekerjaannya dan seberapa puas dengan hasil kerjanya.

Luthans (2011:243) menyatakan beban kerja artinya setiap karyawan melaksanakan tugas pekerjaan yang dipercayakan untuk dikerjakan dan dipertanggung jawabkan oleh satuan organisasi atau seorang karyawan tertentu sesuai dengan kemampuan dan kesanggupan sehingga efektivitas kerja akan berhasil dengan baik, tekanan beban kerja yang berlebihan dapat meningkatkan atau mengarah ke peningkatan terjadinya burnout. Berdasarkan pemahaman tersebut dapat dirumuskan hipotesis pertama sebagai berikut.

$\mathrm{H}_{1}$ : beban kerja berpengaruh positif terhadap burnout.

Robbins (2008:112) menjelaskan adanya penerapan beban kerja membuat karyawan dituntut untuk mengeluarkan seluruh potensi yang dimiliki. Beban kerja yang tinggi dapat menjadi suatu masalah bagi setiap orang yang akan meningkatnya terjadinya work family conflict. Luthans (2007:112) mengatakan hal yang sama semakin tingginya beban kerja yang di alami karyawan akan memberikan dampak positif signifikan pada kejenuhan kerja (burnout) seorang karyawan dan konflik pekerjaan keluarga yang memberikan dampak buruk bagi karyawan. Berdasarkan pemahaman tersebut dapat dirumuskan hipotesis kedua sebagai berikut.

$\mathrm{H}_{2}$ : beban kerja berpengaruh positif terhadap work family conflict.

Kejenuhan kerja (burnout) adalah suatu kondisi fisik, emosi dan mental yang sangat drop oleh situasi kerja yang sangat menentukan karyawan pada perusahaan (Robbins, 2008:211). Work-family conflict memiliki pengaruh positif terhadap 
burnout, artinya semakin tinggi konflik yang dialami maka semakin tinggi burnout yang dialami karyawan. Berdasarkan sisi work-family conflict, seseorang yang memiliki jam kerja yang lama maka akan merasa kesulitan dalam menyeimbangkan tuntutan atas pekerjaan dan keluarga sehingga timbul tekanan atau stres dalam dirinya dan berdampak pada menurunnya kepuasan kerja dan keinginan untuk keluar atau pindah dari organisasi tersebut. Permasalahan konflik pekerjaan keluarga tentu saja menjadi penyebab terjadinya kejenuhan kerja pada diri karyawan, karena tidak sesuai harapan karyawan dengan ketentuan yang ditetapkan oleh perusahaan (Luthans, 2011:119). Berdasarkan pemahaman tersebut dapat dirumuskan hipotesis pertama sebagai berikut.

$\mathrm{H}_{3}$ : work family conflict berpengaruh positif terhadap burnout.

Robbins (2008:246) menjelaskan masalah burnout adalah masalah yang sering dialami oleh setiap orang, pertama disebabkan oleh beban kerja yang berlebihan menimbulkan stress, work family conflict dalam keluarga sehingga timbulnya permasalahan-permasalahan yang dapat meningkatkan keinginan karyawan untuk keluar dari perusahaan. Work family conflict bisa timbul dari tuntutan waktu yang sulit sehingga dapat menyebabkan stres, stres berasal dari satu peran yang spills over ke peran lain kemudian mengganggu kualitas hidup, dan perilaku karyawan untuk keluar dari perusahaan (burnout) (Hariandja, 2008:98). Berdasarkan pemahaman tersebut dapat dirumuskan hipotesis pertama sebagai berikut.

$\mathrm{H}_{4}$ : work family conflict memediasi pengaruh beban kerja terhadap burnout.

Kerangka konsep penelitian dijabarkan dari teori-teori yang ada dan tinjauan pustaka sebagai tuntutan untuk memecahkan masalah penelitian. Rerangka pemikiran dapat berbentuk uraian kualitatif, model matematis, diagram atau persamaan-persamaan yang langsung berkaitan dengan bidang ilmu yang diteliti (Sugiyono, 2013:47).

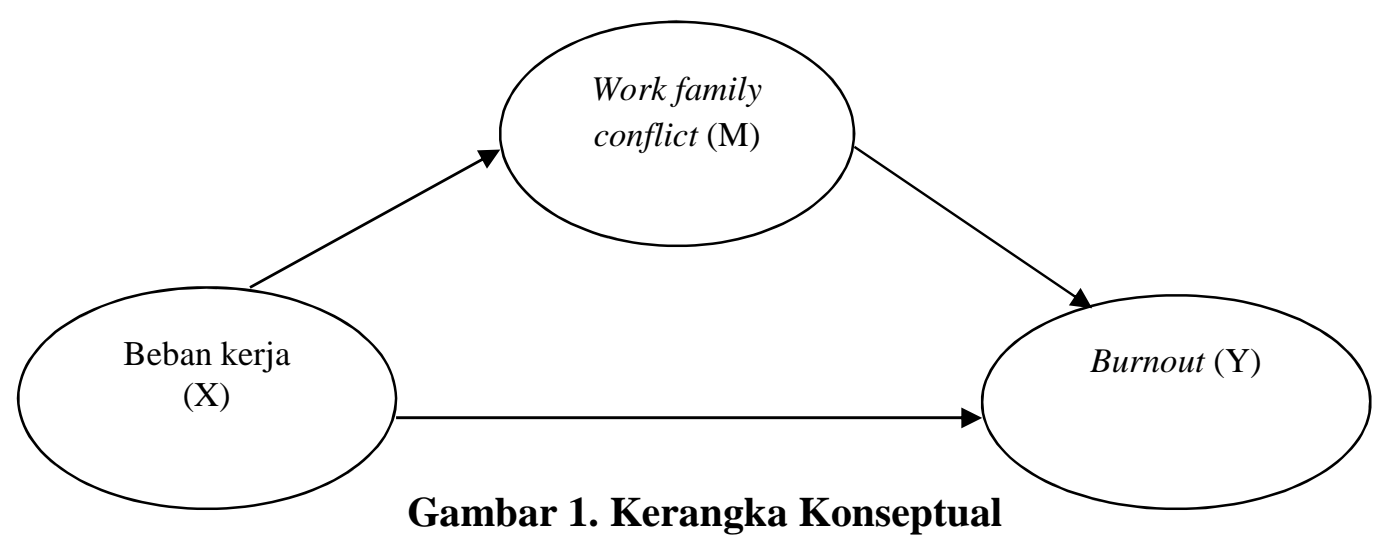

\section{METODE PENELITIAN}

Desain penelitian ini dibuat berdasarkan permasalahan penelitian yang digolongkan pada penelitian asosiatif yang merupakan penelitian yang bertujuan untuk mengetahui pengaruh ataupun hubungan antara dua variabel atau lebih 
(Sugiyono, 2012:56). Penelitian ini dilakukan di PT Bank BRI Persero Tbk Cabang DenpasarGajah Mada yang beralamat di Jalan Gajah Mada No. 5-7 Dauh Puri Kangin Denpasar. Adapun alasan yang melatarbelakangi melakukan penelitian ini mengingat pada perusahaan ini terdapat masalah yang terjadi menyangkut tingginya burnout karyawan dalam pelaksanaan dan penyelesaian pekerjaan yang mengindikasikan masih banyaknya beban kerja yang diberikan perusahaan kepada karyawan. Masih terdapat karyawan yang mengeluh karena beban kerja yang berlebihan sesuai dengan hasil wawancara awal sehingga menimbulkan work familiy conflict yang di alami karyawan.

Obyek penelitian adalah suatu hal atau apa saja yang menjadi perhatian dan apa saja yang diteliti .Sebagai obyek dalam penelitian adalah burnout pada karyawan yang dipengaruhi oleh beban kerja dan work family conflict. Variabel bebas adalah beban kerja (X), work family conflict $(\mathrm{M})$, dan variabel terikat adalah burnout (Y).

Jenis data kuantitatif dan kualitatif yang dipergunakan seperti data jumlah karyawan, jawaban responden terhadap kuesioner dan seperti sejarah perusahaan dan aktivitas perusahaan. Sumber data primer dan sekunder yang dipergunakan seperti observasi dan pemberian kuesioner kepada responden, sejarah berdirinya perusahaan, dan jumlah pelanggan.

Jumlah sampel adalah 61 orang responden dengan menggunakan pengambilan sampel dengan sampel purposive sampling dimana peneliti menentukan pengambilan sampel dengan cara menetapkan ciri-ciri khusus yang sesuai dengan tujuan penelitian sehingga diharapkan dapat menjawab permasalahan penelitian. Data yang dikumpulkan dalam penelitian ini menggunakan metode wawancara, pustaka dan kuesioner yang diberikan kepada responden yang telah dipilih.

Sebuah instrumen dikatakan valid jika mampu mengukur apa yang seharusnya diukur, dan dapat mengungkap data dari variabel yang diteliti secara tepat. Tinggi rendahnya validitas instrumen menunjukkan sejauh mana data yang terkumpul tidak meyimpang dari gambaran tentang variabel yang dimaksud. Santoso (2006:135) menyatakan bahwa item yang mempunyai korelasi positif dengan kriterum (skor total) serta korelasi tinggi menunjukkan bahwa item tersebut mempunyai validitas yang tinggi pula. Syarat minimum untuk dianggap memenuhi syarat adalah kalau $r=0,3$ ". Jadi kalau korelasi antara butir skor dengan skor total kurang dari 0,3 maka butir dalam instrumen tersebut dinyatakan tidak valid.

Uji reabilitas bertujuan untuk mencari tahu sejauh mana kosistensi alat ukur yang digunakan, sehingga bila alat ukur tesebut digunakan kembali untuk meneliti obyek yang sama dan dengan teknik yang sama pula walaupun waktunya berbeda, maka hasil yang akan diperoleh adalah sama. Umar (2004:194) menyatakan bahwa reabilitas adalah suatu angka indeks yang menunjukan kosistensi suatu alat ukur dalam mengukur gejala yang sama. Uji reabilitas mampu menunjukan sejauh mana instrument dapat dipercaya dan diharapkan. Nilai suatu instrumen dikatakan reliabel bila nilai Alpha Cronbach $\geq 0,6$.

Teknik analisis data yang digunakan untuk membahas permasalahan dalam penelitian ini adalah analisis jalur. Analisis jalur dikembangkan sebagai metode untuk mempelajari pengaruh, baik secara langsung maupun tidak langsung 
variabel bebas terhadap variabel tergantung. Analisis ini merupakan salah satu pilihan dalam rangka mempelajari ketergantungan sejumlah variabel di dalam model. Analisis ini merupakan metode yang baik untuk menerangkan apabila terdapat seperangkat data yang lebih besar untuk dianalisis dan mencari hubungan kausal. Suatu diagram jalur akan sangat membantu didalam menganalisis dan menginterpretasikan hubungan yang dihipotesiskan.

Langkah pertama dalam analisis jalur adalah merancang model berdasarkan konsep teoritis yaitu :Variabel beban kerja berpengaruh terhadap burnout, variabel beban kerja berpengaruh terhadap work family conflict, variabel work family conflict berpengaruh terhadap burnout.

Model tersebut juga dapat dinyatakan dalam bentuk persamaan atau diagram jalur sehingga ada yang menamakan sistem persamaan simultan, atau juga ada yang menyebut model struktural.

Langkah kedua adalah pemeriksaan terhadap asumsi yang melandasi analisis jalur. Pemeriksaan terhadap asumsi yang melandasi yaitu hubungan antar variabel adalah linier dan aditif. Model yang digunakan adalah rekursif yaitu sistem aliran kausal satu arah. Model rekursif apabila memenuhi asumsi-asumsi yaitu antar variabel eksogen saling bebas. Pengaruh kausalitas variabel endogen searah. Langkah ketiga dalam analisis jalur adalah pendugaan parameter atau perhitungan koefisien path. Perhitungan koefisien pada gambar diagram path pada uraian sebelumnya. Langkah ke empat dalam analisis jalur adalah pemeriksaan validitas model. Sah tidaknya suatu hasil analisis tergantung dari terpenuhi atau tidaknya asumsi yang melandasinya. Terdapat dua indikator validitas model di dalam analisis jalur yaitu koefisien determinasi total dan theory triming. Langkah terakhir di dalam analisis jalur adalah melakukan interpretasi hasil analisis. Cara melakukan interpretasi model adalah menginterpretasikan hasil atau nilai parameter yang ada. Koefisien yang tidak signifikan nilainyadianggap tidak ada, sedangkan nilai parameter yang signifikan bisa dilihat berapa yang mempunyai pengaruh langsung dan seberapa besar yang berpengaruh tidak langsung. Dari nilai koefisien bisa dilihat variabel mana yang mempunyai pengaruh dominan, mana yang tidak. Menjelaskan (explanation) terhadap fenomena yang dipelajari atau permasalahan yang diteliti. Memprediksi nilai variabel tergantung berdasarkan nilai variabel bebas, yang mana prediksi dengan analisis path ini bersifat kualitatif. Mengidentifikasi faktor determinan, yaitu penentuan variabel bebas mana yang berpengaruh dominan terhadap variabel tergantung dan juga dapat digunakan untuk menelusuri mekanisme (jalur-jalur) pengaruh variabel bebas terhadap variabel tergantung. Menguji model, menggunakan theory trimming untuk uji pengembangan konsep baru.

Pengujian hipotesis mediasi dapat dilakukan dengan prosedur yang dikembangkan oleh Sobel (1982) dan dikenal dengan Uji Sobel (Sobel Test). Uji Sobel digunakan dengan menguji kekuatan pengaruh tidak langsung variabel pengetahuan beban kerja $(\mathrm{X})$ terhadap variabel burnout $(\mathrm{Y})$ melalui variabel work family conflict $(\mathrm{M})$. Pengaruh tidak langsung variabel beban kerja (X) terhadap variabel burnout $(\mathrm{Y})$ melalui variabel work family conflict $(\mathrm{M})$ dihitung dengan cara mengalikan koefisien jalur X terhadap $M$ (a) dengan koefisien jalur $M$ terhadap 
$\mathrm{Y}(\mathrm{b})$ atau ab. Standar error koefisien a dan $\mathrm{b}$ ditulis dengan $\mathrm{S}_{\mathrm{a}}$ dan $\mathrm{S}_{\mathrm{b}}$, besarnya standar error tidak langsung (indirect effect) $\mathrm{S}_{\mathrm{ab}}$.

Pengujian hipotesis mediasi dapat dilakukan dengan prosedur yang dikembangkan oleh Sobel (1982) dan dikenal dengan Uji Sobel (Sobel Test). Uji Sobel digunakan dengan menguji kekuatan pengaruh tidak langsung variabel pengetahuan beban kerja (X) terhadap variabel burnout (Y) melalui variabel work family conflict $(\mathrm{M})$. Pengaruh tidak langsung variabel beban kerja (X) terhadap variabel burnout $(\mathrm{Y})$ melalui variabel work family conflict $(\mathrm{M})$ dihitung dengan cara mengalikan koefisien jalur $\mathrm{X}$ terhadap $\mathrm{M}$ (a) dengan koefisien jalur $\mathrm{M}$ terhadap $\mathrm{Y}(\mathrm{b})$ atau ab. Standar error koefisien a dan b ditulis dengan $S_{\mathrm{a}}$ dan $\mathrm{S}_{\mathrm{b}}$, besarnya standar error tidak langsung (indirect effect) $\mathrm{S}_{\mathrm{ab}}$.

\section{HASIL DAN PEMBAHASAN}

Sebuah instrumen dikatakan valid jika mampu mengukur apa yang seharusnya diukur, syarat minimum untuk dianggap memenuhinya adalah $r=0,3$ ”. Jadi kalau korelasi antara butir skor dengan skor total kurang dari 0,3 maka butir dalam instrumen tersebut dinyatakan tidak valid. Adapun hasil uji validitas dapat dilihat pada Tabel 1. Berikut.

Tabel 1.

Rangkuman Hasil Uji Validitas

\begin{tabular}{clccc}
\hline No & Variabel & Indikator & Korelasi & Keterangan \\
\hline 1 & Burnout $(\mathrm{Y})$ & Y1 & 0,861 & Valid \\
& & Y2 & 0,787 & Valid \\
& & Y3 & 0,624 & Valid \\
& & Y4 & 0,814 & Valid \\
& & Y5 & 0,859 & Valid \\
2 & Beban kerja (X) & Y6 & 0,860 & Valid \\
& & $\mathrm{X} .1$ & 0,747 & Valid \\
& & $\mathrm{X} .2$ & 0,741 & Valid \\
& & $\mathrm{X} .3$ & 0,673 & Valid \\
& & $\mathrm{X} .4$ & 0,807 & Valid \\
& & $\mathrm{X} .5$ & 0,769 & Valid \\
& & $\mathrm{X} .6$ & 0,739 & Valid \\
& & $\mathrm{M} .1$ & 0,743 & Valid \\
& & $\mathrm{M} .2$ & 0,708 & Valid \\
& & $\mathrm{M} .3$ & 0,806 & Valid \\
& & $\mathrm{M} .4$ & 0,697 & Valid \\
& & $\mathrm{M} .5$ & 0,778 & Valid \\
& & $\mathrm{M} .6$ & 0,860 & Valid \\
\hline
\end{tabular}

Sumber : Data diolah, 2019

Tabel 1. diketahui bahwa masih-masing indikator variabel memiliki nilai person correlation lebih besar dari 0,30, maka ini berarti indikator/pertanyaan yang digunakan layak digunakan untuk mengukur apa yang seharusnya diukur, dan dapat mengungkap data dari variabel yang diteliti secara tepat.

Reliabilitas merupakan suatu angka indeks yang menunjukan kosistensi suatu alat ukur dalam mengukur gejala yang sama. Uji reliabilitas mampu menunjukan sejauh mana instrument dapat dipercaya dan diharapkan. Nilai suatu instrumen dikatakan reliabel bila nilai Alpha Cronbach $\geq 0,6$. Adapun hasil uji reliabilitas dapat dilihat pada Tabel 2. berikut 
Tabel 2.

Hasil Uji Reliabilitas

\begin{tabular}{|c|c|c|c|}
\hline No & Variabel & $\begin{array}{l}\text { Cronbach's } \\
\text { Alpha }\end{array}$ & Keterangan \\
\hline 1 & Burnout $(\mathrm{Y})$ & 0,888 & Reliabel \\
\hline 2 & Beban kerja $(X)$ & 0,833 & Reliabel \\
\hline 3 & Work family conflict $(\mathrm{M})$ & 0,857 & Reliabel \\
\hline
\end{tabular}

Tabel 2. diketahui bahwa nilai Cronbach's Alpha untuk masing-masing variabel $>0,6$, ini berarti alat ukur tersebut akan memberikan hasil yang konsisten apabila alat ukur tesebut digunakan kembali untuk meneliti obyek yang sama.

Model jalur yang dibentuk, terdapat dua persamaan struktural atau sistem persamaan simultan. Dari hasil pengolahan data dengan SPSS, model persamaan struktural atau sistem persamaan simultan untuk struktur pertama dan struktur kedua. Hasil pengolahan data dengan SPSS, model persamaan struktural atau sistem persamaan simultan untuk struktur pertama, menunjukkan hasil sebagai berikut :

$$
\begin{array}{llll}
\mathrm{M} & =0.699 \mathrm{X} & & \\
\text { Std Error } & =(.102) & & \\
\mathrm{T} & =(7.515) & & \\
\text { Sig. } & =(0.000) & & \\
\mathrm{R}^{2} & =0.489 & \mathrm{~F}=56,471 & \text { Sig. }=0,000
\end{array}
$$

Berdasarkan laporan di atas, maka diperoleh nilai standar eror sebagai berikut:

$$
\mathrm{P} e_{1}=\sqrt{\left(1-K_{1}^{2}\right.}=\sqrt{1-0,489}=0,714
$$

Menjelaskan hasil pengujian pengaruh variabel beban kerja (X) terhadap work family conflict $(\mathrm{M})$ dijelaskan bahwa beban kerja berpengaruh positif signifikan terhadap work family conflict dengan nilai standardized coefficients beta sebesar 0.699 dan nilai sig t sebesar $0,000<0,05$, oleh karena nilai standardized coefficients beta sebesar 0.699 dengan nilai sig $\mathrm{t}=0,000$ maka $\mathrm{H}_{0}$ diterima. Hal ini berarti variabel beban kerja berpengaruh positif dan signifikan secara parsial terhadap work family conflict karyawan perempuan di PT. Bank BRI Kantor Cabang Denpasar Gajah Mada.

Hasil pengolahan data dengan SPSS, model persamaan struktural atau sistem persamaan simultan untuk struktur struktur kedua, menunjukkan hasil sebagai berikut:

$$
\begin{aligned}
& Y=0.356 X+0.599 \mathrm{M} \\
& \text { Std. Error }=(.110) \quad(.100) \\
& \mathrm{T}=(3.646)(5.728) \\
& \mathrm{Sig}=(0.001)(0.000) \\
& \mathrm{R}^{2}=0.718 \quad \mathrm{~F}=73.698 \quad \mathrm{Sig}=0.000
\end{aligned}
$$
berikut:

Berdasarkan laporan di atas maka persamaan strukturalnya adalah sebagai

$$
\mathrm{Y}=0.356 \mathrm{X}+0.559 \mathrm{M}
$$

Diperoleh nilai standar eror sebagai berikut :

$$
\mathrm{P} e_{2}=\sqrt{\left(1-R_{1}^{2}\right.}=\sqrt{1-0,718}=0,531
$$


Menjelaskan hasil pengujian pengaruh variabel beban kerja (X) terhadap burnout (Y) dijelaskan bahwa beban kerja berpengaruh positif signifikan terhadap burnout dengan nilai standardized coefficients beta sebesar 0,356 dan nilai sig $\mathrm{t}$ sebesar $0,001<0,05$, oleh karena nilai standardized coefficients beta sebesar 0,356 dengan nilai sig $\mathrm{t}=0,001$ maka $\mathrm{H}_{0}$ diterima. Hal ini berarti variabel beban kerja berpengaruh positif dan signifikan secara parsial terhadap burnout karyawan perempuan di PT. Bank BRI Kantor Cabang Denpasar Gajah Mada.

Hasil pengujian pengaruh variabel work family conflict (M) terhadap burnout (Y) dijelaskan bahwa work family conflict berpengaruh positif signifikan terhadap burnout dengan nilai standardized coefficients beta sebesar 0,559 dan nilai sig $\mathrm{t}$ sebesar $0,000<0,05$, oleh karena nilai standardized coefficients beta sebesar 0,559 dengan nilai sig $\mathrm{t}=0,000$ maka $\mathrm{H}_{0}$ diterima.

Output hasil SPSS pengujian pengaruh variabel beban kerja (X) terhadap burnout (Y) dengan mediasi work family conflict (M) digambarkan dengan model diagram jalur seperti pada Gambar 2. berikut.

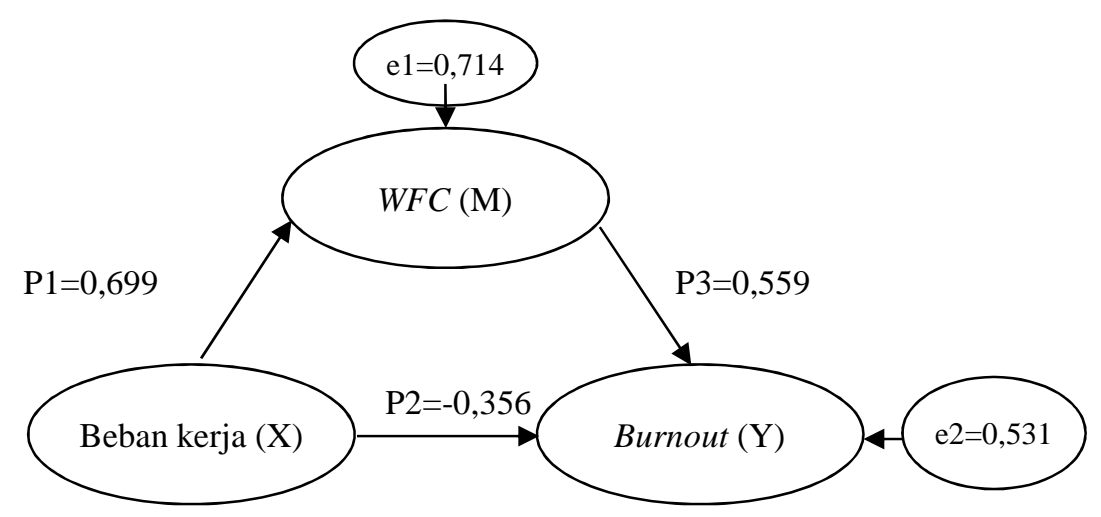

Gambar 2. Model Diagram Jalur Akhir

Gambar 2. menunjukkan nilai koefisien jalur pada model pengaruh beban kerja terhadap variabel burnout melalui work family conflict. Berdasarkan informasi pada Gambar 2 diketahui bahwa koefisien jalur p pengaruh beban kerja terhadap variabel burnout setelah variabel work family conflict dimasukan ke dalam model bernilai 0,559 tidak bernilai 0 , yang berarti work family conflict memediasi pengaruh positif beban kerja terhadap burnout karyawan perempuan di PT. Bank BRI Kantor Cabang Denpasar Gajah Mada.

Menguji signifikansi peran mediasi variabel persepsi harga digunakan rumus Sobel. Berdasarkan diagram jalur pengaruh tidak langsung tersebut, maka dapat dihitung Standar error koefisien a dan $\mathrm{b}$ ditulis dengan $\mathrm{S}_{\mathrm{a}}$ dan $\mathrm{S}_{\mathrm{b}}$, besarnya standar error tidak langsung (indirect effect) $\mathrm{S}_{\mathrm{ab}}$, dari hasil perhitungan didapatkan perbandingan nilai z hitung sebesar 4,293 > z tabel sebesar 0,96, maka Ho ditolak dan Hi diterima. Artinya work family conflict memediasi pengaruh beban kerja terhadap burnout karyawan perempuan di PT. Bank BRI Kantor Cabang Denpasar Gajah Mada.

Berdasarkan perhitungan pengaruh error (Pei), di dapatkan hasil pengaruh error (Peli) sebesar 0,714 dan pengaruh error $\left(\mathrm{Pe}_{2}\right)$ sebesar 0,531. Nilai determinasi total sebesar 0,857 mempunyai arti bahwa sebesar $85,7 \%$ variasi burnout karyawan 
dipengaruhi oleh variabel beban kerja dan work family conflict, sedangkan sisanya sebesar 14,3 persen dijelaskan oleh faktor lain yang tidak dimasukkan ke dalam model.

Hasil analisis data menjelaskan beban kerja memberikan pengaruh positif terhadap burnout karyawan, terlihat adanya beban kerja yang berlebihan memberikan pengaruh positif terhadap sikap burnout karyawan perempuan di PT. Bank BRI Kantor Cabang Denpasar Gajah Mada. Beban kerja yang berlebihan akan menjadi masalah besar apabila tata cara pengelolaannya tidak diperbaiki kedepan oleh manajemen PT. Bank BRI Kantor Cabang Denpasar Gajah Mada, beban kerja yang berlebihan ini akan menimbulkan sikap karyawan yang merasa tidak mampu kembali bekerja karena tekanan kerja, akan timbul perasaan tertekan karena beban pekerjaan yang diterima sehingga merasa tidak mampu bekerja dengan baik, sering merasa gagal dalam menyelesaikan pekerjaan yang akan menimbulkan sikap burnout dari karyawan yang secara langsung akan dapat merugikan perusahaan kedepan. Manajemen PT. Bank BRI Kantor Cabang Denpasar Gajah Mada harus memperhatikan hal ini dengan memperjelas kembali apa yang menjadi beban pekerjaan yang harus diselesaikan karyawan sehingga karyawan senang bekerja tidak merasa terbebani berlebihan secara fisik terutama dibagian staff FO dan AO yang selalu menerima target lebih tinggi dari jabatan lainnya sehingga mampu menyelesaikan pekerjaannya dan merasa puas dalam bekerja sesuai deskripsi pekerjaan untuk menurunkan tingkat burnout karyawan.

Berdasarkan hasil analisis data diketahui bahwa beban kerja memberikan pengaruh positif terhadap work family conflict karyawan. Hal ini mengandung arti bahwa semakin tinggi beban kerja seorang akan menimbulkan tingkat work family conflict yang berlebihan. Pihak manajemen PT. Bank BRI Kantor Cabang Denpasar Gajah Mada sedapat mungkin melihat kembali peran setiap karyawan yang disesuaikan dengan tanggung jawabnya masih-masih apabila ini tidak ditindaklanjuti akan menimbulkan work family conflict yang berlebihan sehingga menganggu psikis karyawan perempuan dikeluarga. Indikasi permasalahan yang dihadapi karyawan merasa jam kerja sering melebihi kapasitas tanggung jawabnya sehingga sering mendapat keluhan dari keluarga, seperti karyawan di bagian kredit (AO, FO, Mantri) yang sering pulang larut malam dikarenakan harus menyelesaikan berkas pinjmanan, merasa tertekan dengan target individu yang terlalu besar dari manajemen sehingga mereka merasa kewalahan dalam bekerja, hal-hal ini membuat karyawan merasa tidak memiliki waktu yang cukup untuk beristirahat bersama keluarga.

Berdasarkan hasil analisis data diketahui bahwa work family conflict memberikan pengaruh positif terhadap burnout karyawan. Hal ini mengandung arti bahwa semakin tinggi work family conflict karyawan di dalam keluarga akan memicu tindakan karyawan untuk melakukan burnout. Manajemen PT. Bank BRI Kantor Cabang Denpasar Gajah Mada harus menyikapi hal ini yang diartikan untuk menghindari terjadinya work family conflict karyawan di dalam keluarga, perilaku work family conflict yang sering terjadi secara langsung akan menganggu fisik dan mental karyawan untuk mencapai level performance yang maksimal. Work family conflict menyebabkan aktivitas mental yang digunakan dalam menyelesaikan pekerjaan lebih dari apa yang mampu dilakukan, sering merasa lelah dan bosan. 
Karyawan sering merasa tidak mampu menyelesaikan pekerjaan karena tekanan waktu yang ada, apabila hal ini berkelanjutan akan secara langsung menyebabkan terjadi sikap burnout karyawan perempuan di PT. Bank BRI Kantor Cabang Denpasar Gajah Mada.

Berdasarkan hasil analisis data diketahui bahwa work family conflict mampu memediasi pengaruh beban kerja terhadap burnout karyawan. Hal ini mengandung arti bahwa beban kerja yang tinggi dirasakan oleh karyawan secara langsung menimbulkan work family conflict yang berlebihan sehingga secara langsung sikap burnout karyawan dalam bekerja akan terjadi. Pihak manajemen PT. Bank BRI Kantor Cabang Denpasar Gajah Mada harus menyadari hal-hal yang menyebabkan hal ini, sesegera mungkin mengevaluasi setiap karyawan dalam bekerja sehingga mampu menghindari hal-hal yang menyangkut dengan waktu karyawan di dalam perusahan dan keluarga agar tidak menimbulkan work family conflict, apabila ini terus berkelanjutan akan menimbulkan perilaku burnout pada karyawan perempuan di PT. Bank BRI Kantor Cabang Denpasar Gajah Mada.

Seorang karyawan yang mengalami beban kerja, agar menjadi evaluasi kedepan oleh pihak manajemen untuk melakukan perubahan dengan kebijakan efektif waktu dan pekerjaan yang diberikan kepada karyawan sehingga mengurangi beban biaya operasional, dan tentunya menurunkan perilaku burnout pada karyawan.

Work family conflict yang menyebabkan terjadinya burnout pada karyawan ini perlu diperhatikan karena karyawan yang sudah menikah akan memiliki peran tanggung jawab ganda yaitu sebagai seorang ibu rumah tangga dan wanita karir.

Sindrom burnout harus diperhatikan pihak manajemen PT. Bank BRI Kantor Cabang Denpasar Gajah Mada yang menetapkan deadline yang tidak masuk akal, hingga lingkungan dengan manajemen tidak sehat kondisi-kondisi ini biasanya yang akan membuat karyawan mengalami tekanan sehingga akan lebih mudah terserang sindrom burnout dengan kelelahan fisik, emosional, dan mental yang juga melibatkan perasaan tidak berguna.

\section{SIMPULAN}

Berdasarkan pada pembahasan pada bab-bab sebelumnya, maka adapun halhal yang dapat disimpulkan yaitu beban kerja berpengaruh positif dan signifikan terhadap burnout pada karyawan perempuan di PT. Bank BRI Kantor Cabang Denpasar Gajah Mada. Beban kerja berpengaruh positif dan signifikan terhadap work family conflict pada karyawan perempuan di PT. Bank BRI Kantor Cabang Denpasar Gajah Mada. Work family conflict berpengaruh positif dan signifikan terhadap burnout pada karyawan perempuan di PT. Bank BRI Kantor Cabang Denpasar Gajah Mada. Workfamily conflict memediasi pengaruh positif beban kerja terhadap burnout pada karyawan perempuan di PT. Bank BRI Kantor Cabang Denpasar Gajah Mada. Berdasarkan simpulan, saran-saran yang dapat diberikan, secara teoritis untuk mengurangi burnout maka yang harus diperhatikan adalah pengaruh mediasi dari Work family conflict. Hal ini disebabkan apabila beban kerja mempengaruhi burnout dengan mediasi Work family conflict akan menyebabkan meningkatnya burnout pada karyawan. Secara Praktis, perilaku burnout yang timbul saat ini perlu ditangani oleh manajemen, karyawan yang merasa kurangnya 
ketersediaan waktu bersama keluarga oleh karena pekerjaan, sehingga mengganggu produktivitas mereka dalam bekerja dan beban kerja karyawan melebihi kapasitas tanggung jawab yang dialami. Manajemen perlu memberikan solusi praktis dalam penyelesaian ini membangun kebersamaan dan rasa memiliki pada perusahaan sehingga ada rasa tanggungjawab untuk membangun produktivitas karyawan dalam bekerja. Permasalahan beban kerja perlu dilakukan perbaikan kedepan dikarenakan karyawan merasa tidak mampu kembali bekerja akibat dari tekanan kerja, yang menimbulkan perasaan tertekan dan merasa gagal dalam menyelesaikan pekerjaan. Perlu peran manajemen untuk melalukan sosialisasi kepada setiap karyawan mengenai kejelasan tugas dan wewenang untuk menyelesaikan pekerjaan sesuai jabatan masing-masing.

Work family conflict yang dialami karyawan timbulnya masalah seperti karyawan sering mengalami tekanan waktu dalam bekerja yang secara langsung akan menganggu fisik dan mental karyawan untuk mencapai level performance yang maksimal. Work family conflict menyebabkan aktivitas mental yang digunakan dalam menyelesaikan pekerjaan lebih dari apa yang mampu dilakukan, sering merasa lelah dan bosan. Manajemen perlu menjembatani permasalahan ini dengan lebih sering mengadakan pertemuan-pertemuan keluarga seperti family gathering, forum diskusi yang melibatkan keluarga pekerja sehingga timbul rasa memiliki satu sama lainnya.

\section{REFERENSI}

Ariana, I., \& Riana, I. (2016). PENGARUH WORK-FAMILY CONFLICT, KETERLIBATAN KERJA DAN STRES KERJA TERHADAP KEPUASAN KERJA KARYAWAN. E-Jurnal Manajemen Universitas Udayana.

Cohen, A., \& Abedallah, M. (2015). The mediating role of burnout on the relationship of emotional intelligence and self-efficacy with ocb and performance. Management Research Review. https://doi.org/10.1108/MRR10-2013-0238

Dewi, C., \& Wibawa, I. (2016). Pengaruh Stres Kerja Dan Motivasi Kerja Terhadap Kinerja Karyawan Pada Pt. Bank Bpd Bali Cabang Ubud. EJurnal Manajemen Universitas Udayana, 5(12), 7583-7606.

Fajriani, A., \& Septiari, D. (2015). Pengaruh Beban Pekerjaan terhadap Kinerja Karyawan : Efek Mediasi Burnout. Akuntansi, Ekonomi Dan Manajemen Bisnis, 3(1), 74-79.

Greenhaus, J. H., \& Beutell, N. J. (1985). Sources of Conflict Between Work and Family Roles. Academy of Management Review.

https://doi.org/10.5465/amr.1985.4277352 
Hariandja. (2008). Manajemen Sumber Daya Manusia. Jakarta: PT Grasindo. Hasibuan. (2018). Manajemen Sumber Daya Manusia. In Manajemen Sumber Daya Manusia.

Khandan, M. (2015). Level of Workload and Its Relationship with Job Burnout among Administrative Staff. International Journal of Occupational Hygiene.

Laeeque, S. H. (2014). Role of Work-Family Conflict in Job Burnout: Support from the Banking Sector of Pakistan. International Letters of Social and Humanistic Sciences. https://doi.org/10.18052/www.scipress.com/ilshs.40.1

Li, C., Lu, J., \& Zhang, Y. (2013). Cross-domain effects of work-family conflict on organizational commitment and performance. Social Behavior and Personality. https://doi.org/10.2224/sbp.2013.41.10.1641

Luthans, F. (2011). Organizational Behavior: An Evidence -Based approach. New York: The McGrow-Hill Companies, Inc.

Luthans, F. (2012). Organizational behavior an evidence-based approach 12th edition. In Organizational behavior: an edivence-based approach.

Maeran, R., Pitarelli, F., \& Cangiano, F. (2013). Work-life balance and job satisfaction among. Interdiscplinary Journal of Family Studies.

Melati, P., Yo, P., Bagus, I., \& Surya, K. (2015). Putu Melati Purbaningrat Yo 1 Fakultas Ekonomi Universitas Udayana ( Unud ), Bali, Indonesia. 4(5), 1149-1165.

Nasir, M. A., \& Morgan, J. (2017). Article information :

Purba, J., Yulianto, A., \& Widyanti, E. (2007). Pengaruh Dukungan Sosial Terhadap Burnout Pada Guru. Jurnal Psikologi.

Puspitasari, D. A., \& Handayani, M. M. (2014). Hubungan Tingkat Self-Efficacy Guru dengan Tingkat Burnout pada Guru Sekolah Inklusif di Surabaya. Jurnal Psikologi Pendidikan Dan Perkembangan.

Robbins, S., \& Judge, T. A. (2013). Perception and Individual Decision Making. In Organizational Behavior.

Robbins, S. P. (1994). Teori Organisasi: struktur, Desain dan Aplikasi. In Jakarta: Arcan.

Robbins, S. P. (2008). Teori organisasi, struktur, desain, dan aplikasi. (Alih Bahasa: Tim Indeks). New Jersey: Prentice Hall. 
Robins, S. P., \& Coulter, M. (2012). Management. In Angewandte Chemie International Edition. https://doi.org/10.1002/15213773(20010316)40:6<9823::AID-ANIE9823>3.3.CO;2-C

Salam, F. (2014). Work Overload, Work-Family Conflict, Family-Work Conflict and Their Effects on Job Embeddedness: The Moderating Role of Coworker Support. IOSR Journal of Business and Management. https://doi.org/10.9790/487x-16157580

Santoso, S. (2006). Buku Latihan SPSS Statistik Parametrik. Jakarta : Elex Media Komputindo.

Selvarajan, T. T., Singh, B., \& Cloninger, P. A. (2016). Role of personality and affect on the social support and work family conflict relationship. Journal of Vocational Behavior. https://doi.org/10.1016/j.jvb.2016.02.004

Siagian, S. P. (2015). Manajemen Sumber Daya Manusia. In Jakarta : Bumi Aksara.

Sobel, M. E. (1982). Asymptotic Confidence Intervals for Indirect Effects in Structural Equation Models. Sociological Methodology. https://doi.org/10.2307/270723

Sonny, H. (2012). Analisis Pengaruh Pengembangan SDM Terhadap Kinerja Pegawai Pada Badan Kepegawaian Daerah Kabupaten Karawang. Jurnal Manajemen.

Sugiyono. (2013). . Metode Penelitian Bisnis. Bandung : CV. Alvabeta.

Talachi, R. K., \& Gorji, M. B. (2013). Evaluating the Relationship between Job Burnout and Organizational Citizenship Behavior : A Study of Industry, Mine and Trade Organization Employees. Oman Chapter of Arabian Journal of Business and Management Review. https://doi.org/10.12816/0002319

Umar. (2004). Riset Sumber Daya Manusia dan Administrasi (Edisi Revi). Jakarta: PT. Gramedia Pustaka Utama. 